\title{
4. Pursuing global socio-economic, colonial and environmental justice through economic redistribution: the potential significance of human rights treaty obligations
}

Ralph Wilde ${ }^{l}$

In the developing countries most of the environmental problems are caused by under-development. Millions continue to live far below the minimum levels required for a decent human existence, deprived of adequate food and clothing, shelter and education, health and sanitation. Therefore, the developing countries must direct their efforts to development, bearing in mind their priorities and the need to safeguard and improve the environment. For the same purpose, the industrialized countries should make efforts to reduce the gap between themselves and the developing countries.

Environmental deficiencies generated by the conditions of under-development and natural disasters pose grave problems and can best be remedied by accelerated development through the transfer of substantial quantities of financial and technological assistance as a supplement to the domestic effort of the developing countries and such timely assistance as may be required.

Stockholm Declaration 1972, preamble, para 2, and Principle $9^{2}$

The greatest and most significant achievement during the last decades has been the independence from colonial and alien domination of a large number of peoples and nations which has enabled them to become members of the community of free peoples. Technological progress has also been made in all spheres of economic activities in the last three decades, thus providing a solid potential for improving the well-being of all peoples. However, the remaining vestiges of alien and colonial domination, foreign occupation, racial discrimination, apartheid and neo-colonialism in all its forms continue to be among the greatest obstacles to the full emancipation and progress of the developing countries and all the peoples involved. The benefits of technological progress are not shared equitably by all members of the international community. The developing countries, which constitute 70 per cent of the world's population, account for only 30 per cent of the world's income. It has proved impossible to achieve

an even and balanced development of the international community under the existing international economic order. The gap between the developed and the developing countries continues to widen in a system which was established at a time when most of the developing countries did not even exist as independent States and which perpetuates inequality.

1 This chapter is an open access work distributed under the Creative Commons Attribution-No n-Commercial-NoDerivatives 3.0 Unported (https://creativecommons.org/licenses/by-nc-nd/3.0/). Users can redistribute the work for non-commercial purposes, as long as it is passed along unchanged and in whole, as detailed in the License. Edward Elgar Publishing Ltd must be clearly credited as the owner of the original work. Any translation or adaptation of the original content requires the written authorization of Edward Elgar Publishing Ltd.

2 Stockholm Declaration on the Human Environment (16 June 1972) UN Doc A/Conf.48/14. 
Declaration on the New International Economic Order, UNGA 1974³

States have $[\ldots]$ the responsibility to ensure that activities within their jurisdiction or control do not cause damage to the environment of other States or of areas beyond the limits of national jurisdiction.

In view of the different contributions to global environmental degradation, States have common but differentiated responsibilities. The developed countries acknowledge the responsibility that they bear in the international pursuit of sustainable development in view of the pressures their societies place on the global environment and of the technologies and financial resources they command.

States shall $[\ldots]$ cooperate in an expeditious and more determined manner to develop further international law regarding liability and compensation for adverse effects of environmental damage caused by activities within their jurisdiction or control to areas beyond their jurisdiction.

Rio Declaration 1992, principles 2, 7 and $13^{4}$

We are meeting at a time of immense challenges to sustainable development. Billions of our citizens continue to live in poverty and are denied a life of dignity. There are rising inequalities within and among countries. There are enormous disparities of opportunity, wealth and power.

Transforming our World: The 2030 Agenda for Sustainable Development, UNGA 20155

\section{INTERNATIONAL EFFORTS AT PROMOTING GLOBAL ECONOMIC REDISTRIBUTION TO REALIZE SOCIAL RIGHTS}

As far as the realization of social rights is concerned - the right to food and nutrition, housing, healthcare, education, all within a framework of a sustainable natural environment - three central interrelated challenges are commonly made to the state of the global economy, especially by people, including those of first nation/indigenous heritage, in economically underprivileged, so-called developing countries - notably countries that were formed out of colonies - in the Global South/Third World. The first two challenges became prominent in the agenda for a New International Economic Order (NIEO), as reflected in the above quoted 'Declaration on the New International Economic Order' (NIEO Declaration), the associated 'Programme for Action' (NIEO Programme of Action) and the subsequent 'Charter on the Economic Rights and Duties of States' (NIEO Charter), adopted by the UN General Assembly (UNGA) in $1974 .{ }^{6}$ In the first place there is the 'economic injustice' challenge: global

3 UNGA Res 3201 (S-VI) (1 May 1974) 'Declaration on the Establishment of a New International Economic Order', para 1.

4 Rio Declaration on Environment and Development (10 August 1992) UN Doc A/CONF.151/26.

5 UNGA Res A/70/1 (25 September 2015) 'Transforming Our World: The 2030 Agenda for Sustainable Development', para 14.

6 NIEO Declaration 1974 (n 3); UNGA Res 3202 (S-VI) (1 May 1974) 'Programme of Action on the Establishment of a New International Economic Order'; UNGA Res 3281 (XXIX) (12 December 1974) 'Charter of Economic Rights and Duties of States'. On the NIEO, see, e.g., Mohammed Bedjaoui, Towards a New International Economic Order (1979); Francisco V Garcia-Amador, 'The Proposed New International Economic Order: A New Approach to the Law Governing Nationalization and Compensation' (1980) 12 Lawyers of the Americas 1; Kamal Hossain (ed.), Legal Aspects of the New International Economic Order (1980); John Linarelli, Margot E Salomon and Muthucumaraswamy 
socio-economic inequality is an injustice that should be resisted, and this should form the basis for reconceiving international economic relations and the global distribution of wealth and resources in order to promote social rights in the Global South. ${ }^{7}$ In the second place is the 'colonial justice' challenge: that there has to be a reckoning for the injustice of colonialism - both in and of itself, and also when it comes to the abuses and exploitation of the colonial era, from the extermination and subjugation of indigenous/first nation peoples to slavery and the trade in enslaved people; the destruction, spoliation and plunder of the environment in general and material resources and cultural artefacts in particular; and the abuses, including massacres, perpetrated against colonial peoples in general and indigenous/first nation peoples in particular. ${ }^{8}$ In the third place is the 'environmental justice' challenge, reflected in the foregoing quotes from the Stockholm and Rio conferences in 1972 and 1992: that 'industrialized' countries, whose economic privileges are rooted in environmental harm and exploitation generally, and climate-altering carbon use in particular (an issue that emerged as a mainstream international concern in the runup to Rio), owe a debt to the people in the world who have been and are at the sharp end of much of this harm and exploitation generally, and to people who are suffering and will suffer the most from the damaging effects of carbon use-based climate change in particular. ${ }^{9}$

The 'colonial justice' challenge is raised both as a matter in its own right and because of its relationship to the 'economic injustice' and 'environmental justice' challenges, given the way in which current socio-economic and environmental inequalities - the sharp difference in the realization of social rights and associated environmental conditions across the world, and the environmentally harmful basis on which the economically privileged parts of the world attained this privilege - can in part be linked back to the colonial and imperial structures of the past. One link would be in how industrialization in the west - and the consequences this had for the enhancement of social rights of people there, with its ongoing legacy in terms of socio-economic inequality and environmental destruction, including catastrophic climate alteration - was bound up in and enabled by slavery, the trade in enslaved people, the imposition of unequal trade relations, the exploitation of people, the plunder of natural resources

Sornarajah, The Misery of International Law: Confrontations with Injustice in the Global Economy (2018) chapter 3. On the NIEO and the broader critiques of the global economic order see, e.g., B Chimni, 'Third World Approaches to International Law: A Manifesto' (2006) 8(1) International Community Law Review 3.

7 See the sources cited ibid.

$8 \mathrm{Ibid}$. On slavery and the trade in enslaved people in particular, see also the more recent coverage of the issue, reflecting post-NIEO developments in it, in Hilary Beckles, Britain's Black Debt: Reparations for Caribbean Slavery and Native Genocide (2013); Ana L Araujo, Reparations for Slavery and the Slave Trade: A Transnational and Comparative History (2017).

9 Note also the observation from the 1991 Beijing Declaration on Environment and Development issued by the foreign ministers of developing countries, that 'the developed countries bear responsibility for the degradation of the global environment. Ever since the Industrial Revolution, the developed countries have over-exploited the world's natural resources through unsustainable patterns of production and consumption, causing damage to the global environment, to the detriment of the developing countries.' Quoted in Dinah Shelton, 'Equitable Utilization of the Atmosphere: A Rights-Based Approach to Climate Change?' in Stephen Humphreys (ed.), Human Rights and Climate Change (2010) 121. On this topic see, e.g., the review and sources cited in Benoit Mayer, 'State Responsibility and Climate Change Governance: A Light through the Storm' (2014) 13 Chinese Journal of International Law 539, section II, and the discussion in Shelton, section E. 
and environmental harm in colonial territories. ${ }^{10}$ Another link would be the way in which the colonial legacy of externally imposed arbitrary boundaries forming contours for the borders of post-colonial states set many newly independent states up as entities with considerable challenges in forming cohesive and functioning political and socio-economic communities, placing them at a disadvantage in this regard compared to many western states. ${ }^{11}$ Relatedly, it has been argued ever since decolonization that independence has to mean not only (and perhaps not even, given what has been said) formal, legal sovereign statehood but also substantive socio-economic liberation and emancipation, bearing in mind the foregoing link between western industrialization and colonial subjugation and economic exploitation and the plundering of resources, as well as the ongoing foreign ownership of land, material and natural resources in former colonial states and the inability of former colonial states to be able to repatriate these resources fully, or even at all. ${ }^{12}$

Thus, it is argued, it is not possible to address the socially, economically and environmentally unequal world as it is now without an appreciation of the historical context which both contributed to this inequality and also suggests a series of unresolved injustices. Moreover, the continuing operation of foreign socio-economic privileges that have their origins in the colonial period are compounded by other forms of economic domination in the 'post-colonial' era, some of which are also linked back to colonial arrangements, such as the disciplining role of the international financial institutions such as the World Bank and the International Monetary Fund; the substantive policies of what is euphemistically termed 'structural adjustment' invariably, massive cuts to social provision and privatization linked to foreign corporate ownership - that they and other global and inter-state financial arrangements impose; the unequal terms of global trade (with socio-economically privileged states protecting their industries); the frequent use of development 'aid' also to impose the aforementioned 'structural adjustment' and subsidize the industries/companies of 'assisting' states, thereby 'under-developing' their equivalents in less socio-economically privileged countries, undermining the ostensible underlying rationale for assistance in the first place; the global regime of rules protecting foreign ownership of assets and natural resources in socio-economically underprivileged countries ('investment protection'), effectively preventing the nationalization and so repatriation of such assets and resources without full compensation (which would cancel out the benefits); and the national and global rules on intellectual property, which enable the corporate ownership of plants and seeds and pharmaceuticals, leading to foreign monopolistic ownership of and the setting of high prices for basic foodstuffs and drugs in socio-economically underdeveloped countries, in the case of drugs making it difficult for more affordable generics to be produced..$^{13}$ As a result of these and other developments, a distinctive 'neo-colonial' basis for the 'economic inequality' challenge is raised: dynamics equivalent to the historical practices

10 For the example of the UK see, e.g., Catherine Hall et al, Legacies of British Slave-Ownership: Colonial Slavery and the Formation of Victorian Britain (2014).

${ }_{11}$ See Makau wa Mutua, 'Why Redraw the Map of Africa: A Moral and Legal Inquiry' (1994) 16 Michigan Journal of International Law 1113.

${ }_{12}$ See, e.g., the discussion in Linarelli, Salomon \& Sornarajah (n 6), passim, especially chapters 3-6, and Chimni (n 6), passim.

13 See, e.g., Chimni (n 6), passim; Linarelli, Salomon \& Sornarajah (n 6), passim; Balakrishnan Rajagopal, International Law from Below: Development, Social Movements, and Third World Resistance (2003) Part II; Jason Hickel, The Divide: A Brief Guide to Global Inequality and its Solutions (2018). 
that give rise to the 'colonial justice' challenge continued after those historical practices came to an end with 'decolonization'. ${ }^{14}$

One assertion that has been made in relation to the first two challenges, which was central to the NIEO agenda, is that there should be a radical, transformatory global transfer of economic wealth from the globally socio-economically privileged to the globally socio-economically underprivileged..$^{15}$ For the 'economic inequality' challenge, this amounts to a socialist, solidaristic mechanism of redistribution as a means of meeting the challenge and enhancing social rights for people in the Global South. For the 'colonial justice' challenge, this is posited as a form of redress/reparation (and would include the restitution of plundered cultural artefacts as an important component). This idea of a global transfer of wealth is implicated in the related 'environmental justice' challenge, as again a form of redress/reparation, in this case for environmental harm in general and the effects of climate change in particular.

The 'global economic redistribution' agenda would conceptualize the area of state practice within which resource and technology transfers from the rich to the poor operate, for example through international assistance/aid programmes and debt forgiveness aimed at enhancing the social rights of the global poor, as a matter of obligation not discretion.

The international system, it is claimed, has a normative dimension, a field of binding rights and obligations - international law - and an institutional structure of global governance - the United Nations, and other international organizations. The NIEO initiative, whose foundational 1974 Declaration is extracted above, was an initiative by newly independent, former colonial states. Many of these states acted collectively through the Non-Aligned Movement and the Group of 77 countries (G77) to utilize the global normative and institutional system to reconceive global economic relations for the post-decolonization era, addressing the aforementioned challenge of global socio-economic inequality on the 'post-colonial' basis outlined above. ${ }^{16}$

Various regimes were adopted to enshrine norms within the international legal system that had potential relevance to this agenda, some of which were furthered within the United Nations, and which were often linked to the purposes and principles and Chapter IX of the UN Charter, which set out the promotion of economic development through international cooperation as an objective of the organization and pledge of its member states. ${ }^{17}$ A significant normative development and precursor to the NIEO Declaration was the 'Declaration on Principles of International Law concerning Friendly Relations and Co-operation among States in Accordance with the Charter of the United Nations' adopted by the General Assembly in $1970 .{ }^{18}$ Commonly referred to by shorthand as the 'Friendly Relations Declaration' because of its provisions concerning non-intervention and the use of force, and reflecting the commonplace prioritization of security over social rights and welfare concerns, the Declaration

14 On this 'neocolonial' critique, see the sources cited in Ralph Wilde, International Territorial Administration: How Trusteeship and the Civilizing Mission Never Went Away (2008) sources list 5.3.3, from p.538.

${ }_{15}$ See the sources cited above, $\mathrm{n} 5$.

16 See the sources cited above, $\mathrm{n} 5$.

17 Charter of the United Nations (26 June 1945) 892 UNTS 119, Chapter IX in general, and Arts 55 and 56 therein in particular.

18 UNGA Res 2625 (XXV) (24 October 1970) 'Declaration on Principles of International Law concerning Friendly Relations and Co-operation among States in accordance with the Charter of the United Nations'. 
is significant for present purposes because of its 'cooperation' aspects, articulating a duty to cooperate in general and to promote economic growth and social rights globally in particular.

The NIEO initiatives covered a broad set of measures, such as attempts to challenge the terms of global trade and renationalize assets, including those relating to natural resources owned by foreign companies and nationals, as a way of enhancing social rights in the Global South. These were set out in the aforementioned NIEO Declaration, NIEO Programme of Action and NIEO Charter. ${ }^{19}$ Significantly for present purposes, a key component of these three instruments was an agenda calling for a significant increase in financial, resource and technology transfer from socio-economically privileged countries to socio-economically underprivileged countries, and a reckoning, including through compensation, for colonial domination itself and the abuses and exploitation conducted through it.

Other notable initiatives include the 1986 General Assembly Resolution enshrining a 'Declaration on the Right to Development'; various decisions fixing certain targets of GDP/ GNI for OECD states to allocate to development assistance; the Millennium Declaration and its associated Millennium Development Goals (MDGs) of 2000; and the successor to these, the Sustainable Development Declaration (the 2035 Agenda resolution quoted above), and associated Sustainable Development Goals (SDGs) of 2015, both adopted by the UNGA, articulating regimes of cooperation and expressions of solidarity in realizing socio-economic rights globally, and setting targets for global poverty reduction and health, gender equality, child mortality, environmental protection and educational outcomes. ${ }^{20}$

The NIEO agenda was resisted by the socio-economically privileged west, notably when it concerned economic redistribution and the expropriation of foreign-owned assets. As reflected in the foregoing quote from the General Assembly in 2015, global socio-economic inequality has persisted; significant redistributive capital and resource flows from the global rich the global poor have not happened and, indeed, flows have continued to move in the opposite direction when it comes to the human, material (including land) and resource capital shifts in

\footnotetext{
19 Cited above, $\mathrm{n} 5$.

20 UNGA Res 41/128 (4 December 1986) 'Declaration on the Right to Development'; UNGA Res 1161 (XII) (26 November 1957) 'Balanced and Integrated Economic and Social Progress'; UNGA Res 2542 (XXIV) (11 December 1969) 'Declaration on Social Progress and Development'. See also the final acts of the two International Conferences on Human Rights: Teheran (1968) and Vienna (1993): Final Act of the International Conference on Human Rights (22 April-13 May 1968) UN Doc A/CONF.32/41, II, Proclamation of Teheran, and Resolutions XVII and XXI; Vienna Declaration and Programme of Action (12 July 1993) UN Doc A/CONF.157/23; see also the resolutions of the UN Commission on Human Rights: Resolution 4 (XXXIII) of 21 February 1977; Resolution 4 (XXXV) of 2 March 1979; Resolution 36 (XXXVII) of 11 March 1981. There have been a number of working groups on the right to development within the UN Commission on Human Rights. In addition, in 1998 an 'independent expert' was appointed, who in 1999 expressed the view that 'Every State which recognized the right to development was obliged to take positive action to assist the citizens of other States in realizing those rights' (HRComm, Summary Record of the 9th meeting, 55th Session (30 March 1999) UN Doc E/CN.4/1999/ SR.9, para 29); see also, e.g., the Fifth Report of the Independent Expert on the Right to Development, Frameworks for Development Cooperation and the Right to Development (18 September 2002) UN Doc E/CN.4/2002/WG/18/6. On the targets for GNI/GDP, see the discussion in Ralph Wilde, 'Dilemmas in Promoting Global Economic Justice through Human Rights Law' in Nehal Bhuta (ed.), The Frontiers of Human Rights (2016) chapter 5, 162-63 and sources cited therein. On the MDGs see UNGA Res 55/2 (8 September 2000) 'United Nations Millennium Declaration', paras 5, 11, 13, 15-16. On the SDGs, see the sources cited above, $\mathrm{n} 2$.
} 
the global economy. The adoption of the SDGs reflected the failure of the targets set in the MDGs - which had in any case been modest - to be met. ${ }^{21}$

As a matter of international law, the NIEO agenda in general, and most of the foregoing initiatives mentioned, were furthered primarily within the UNGA, a body where each formally 'sovereign' state has an equal vote, and where the process of decolonization had created a situation where socio-economically underprivileged and former colonial states were in the majority. However, and reflecting how ideas of formal independence and sovereign equality cohabit with de facto relations of domination, dependency and inequality, General Assembly Resolutions that set out general regimes of standards for member states are not in and of themselves binding, even if they use the language of rights and/or obligations in them - so-called 'soft law'. ${ }^{22}$ Such resolutions are usually understood as somehow merely aspirational and discretionary. ${ }^{23}$ By contrast, the 15 -member Security Council - with five permanent and veto-wielding states, none of which are from the Third World - can 'make law', in the sense of introducing new substantive legal rights and/or obligations operative on some or all of the member states of the UN, directly through its resolutions.

Former colonial states, then, having had to accept the idea of statehood and an associated national identity operating along the lines of externally imposed colonial boundaries as the price of independence from formal colonial rule, were also faced with an international system of global governance - the United Nations - which, as a matter of formal differences in law-making capacities, institutionalized and perpetuated their subordination, preventing legal change on their terms as a matter of the formalities of that organization. This block on majority-based change necessarily also meant preservation of the status quo in international law, which therefore bolstered the absence of a norm concerning global economic redistribution.

The MDGs and the SDGs, supported by socio-economically privileged countries, are also in this 'soft law' category of General Assembly resolutions, and the targets for aid made by those within the privileged OECD club are similarly through instruments that are not formally binding. These undertakings could have been enshrined in binding treaties, as has been the case with some instruments that start off as UNGA resolutions or other non-binding declarations. This did not happen.

By contrast, 'hard law' continued, and its substantive content developed in order to undergird all the aforementioned 'neo-colonial' arrangements. The trade rules that enable the protection of western economies; inter-state and IFI financial arrangements with 'structural adjustment' policies requiring a reduction in social provision and privatization enabling foreign corporate ownership; development 'aid' provision with similar policies, and also used to protect the industries/companies of 'assisting' states; intellectual property and investment protection norms that enable foreign ownership and the setting of higher prices for foodstuffs

\footnotetext{
$21 \quad$ Sustainable Development Declaration 2015 (n 5), paras 2 and 16.

22 On 'soft law' see, e.g., Dinah Shelton, 'Soft Law' in David Armstrong et al (eds), Routledge Handbook of International Law (2008); Daniel Thürer, 'Soft Law' in MPEPIL < https://opil.ouplaw.com/ view/10.1093/law:epil/9780199231690/law-9780199231690-e1469?prd=EPIL> (29 November 2019).

23 Although the principles they contain may relate to norms in customary international law, because they codify such norms already existing as a matter of custom, or the affirmation of them by states in the resolutions has significance in the formulation of customary norms. For a classic treatment of this topic see, e.g., Rosalyn Higgins, The Development of International Law through the Political Organs of the United Nations (1963).
} 
and pharmaceuticals in socio-economically underprivileged countries: all of these arrangements are enshrined in binding international legal treaties (and also customary international law when it comes to investment protection, via the pre-decolonialization-era legal rules of 'diplomatic protection' covering the property of aliens which newly independent former colonial states were unable to alter). ${ }^{24}$

On the topic of environmental justice in particular, there has long been an acceptance of certain liabilities for particular forms of transboundary harm, as reflected in the aforementioned assertion in principle 2 of the Rio Declaration. ${ }^{25}$ However, as currently understood, this falls short of a full-spectrum, universally applicable regime to address all elements of the environmental justice agenda, notably as far as historical harms, and climate change, are concerned. Indeed, the issue of transboundary liability and associated compensation for the effects of climate change in particular has been a hugely contested issue in international climate change negotiations, despite the aforementioned aspirational pledge made in principle 13 of the Rio Declaration in 1992. ${ }^{26}$ Whereas the Warsaw International Mechanism for Loss and Damage Associated with Climate Change Impacts was adopted in 2013, there is not even clear and general international agreement on whether loss and damage caused by climate change is something that should involve transboundary liability and compensation, as opposed to being addressed only within regimes concerned with adaptation. ${ }^{27}$ Commentators have therefore tended to address the issue of transboundary liability and compensation on this topic only as an arena of potential future normativity. ${ }^{28}$

However, separate from the NIEO-associated soft law initiatives and the ongoing climate change regime negotiations, a separate area of international law, which originated in a (soft law) UNGA resolution, emerged within an overlapping timeframe of the Stockholm conference and the NIEO initiatives, and ended up being enshrined in binding 'hard law' treaties: international human rights law. The foundational instrument here, the 1948 Universal Declaration on Human Rights (UDHR), built on the aforementioned provisions of Chapter IX of the UN Charter to articulate socio-economic rights and the requirement of international cooperation in the realization of these rights, as well as a more general objective of an international order within which all rights can be fully realized. ${ }^{29}$ This instrument, as a UNGA Resolution, has 'soft law' status like the foregoing regimes. ${ }^{30}$ But unlike those regimes, it

24 See the sources cited above, $\mathrm{n} 12$.

25 See, e.g., Alexandre Kiss and Dinah Shelton, Guide to International Environmental Law (2007) chapter V, section A; Günther Handl, 'Transboundary Impacts' in Daniel Bodansky, Jutta Brunnée and Ellen Hey (eds), The Oxford Handbook of International Environmental Law (2008) and sources cited therein.

${ }_{26}$ See the discussion in Daniel Bodansky, Jutta Brunnée and Lavanya Rajamani, International Climate Change Law (2017) 137 and 239, and sources cited therein.

27 Ibid.

28 See, e.g., Daniel Farber, 'Basic Compensation for Victims of Climate Change' (2007) 155(6) University of Pennsylvania Law Review 1605; Mayer (n 9), passim; Christina Voigt, 'State Responsibility for Climate Change Damages' (2008) 77 Nordic Journal of International Law 1; Roda Veryheyen and Peter Roderick, 'Beyond Adaptation: The Legal Duty to Pay Compensation for Climate Change Damage' (2008) WWF UK, and sources cited therein.

29 UNGA Res 217/A (III) (10 December 1948) 'Universal Declaration of Human Rights', Arts 22 and 28 .

30 For a discussion of the idea that the norms in the UDHR are part of customary international law see, e.g., Hurst Hannum, 'The Status of the Universal Declaration of Human Rights in National and International Law’ (1995-96) 25 Georgia Journal of International and Comparative Law 287. 
was followed by binding international human rights treaties. ${ }^{31}$ Moreover, as will be indicated, some of these treaties address the subject of economic, social and cultural rights. Furthermore, more generally, human rights treaties have come to be understood as encompassing norms concerned with the environment. ${ }^{32}$

The relevant instruments addressing economic, social and cultural rights are the Additional Protocol to the ACHR in the Area of Economic, Social and Cultural Rights (I-A PESC), the African Charter of Human and Peoples' Rights (AfCHPR) and its Protocol (a separate treaty) on the Rights of Women in Africa (AfCHPR Women's Rights Protocol), the Arab Charter on Human Rights, the Convention on the Elimination of Discrimination Against Women (CEDAW), the Convention on the Elimination of Racial Discrimination (CERD), the Convention on the Rights of the Child (CRC) and its first two Protocols - on prostitution and pornography - and armed conflict (hereinafter CRC Protocols 1 and 2), the Convention on the Rights of People with Disabilities (CRPD), the European Social Charter, the Inter-American Convention on the Elimination of All Forms of Discrimination against Persons with Disabilities (CIADDIS) and the International Covenant on Economic, Social and Cultural Rights (ICESCR). ${ }^{33}$

31 And also further non-treaty soft law instruments such as UNGA Res 61/295 (13 September 2007) 'United Nations Declaration on the Rights of Indigenous Peoples'.

32 On human rights law and the environment see, e.g., Dinah Shelton, 'Human Rights, Environmental Rights, and the Right to Environment' (1991) 28 Stanford Journal of International Law 103; Stephen Humphreys (ed.), Human Rights and Climate Change (2010) and sources cited therein. Notable international decisions include the Precautionary Measures Order by the Inter-American Commission on Human Rights, PM 382/10 - Indigenous Communities of the Xingu River Basin, Pará, Brazil (adopted 1 April 2011, revised 29 July 2011); The Environment and Human Rights, IACtHR, Advisory Opinion OC-23/17 of 15 November 2017; HRCttee, 'General Comment No 36' (30 October 2018) CCPR/C/ GC/36, paras 26, 62; Portillo Cáceres v Paraguay, HRCttee, Communication No 2751/2016, CCPR/ C/126/D/2751/2016 (2019); Ioane Teitota v New Zealand, HRCttee, Communication No 2728/2016, CCPR/C/127/D/2728/2016 (2020), paras. 9.4-9.14 and para 10.

33 Additional Protocol to the American Convention on Human Rights in the Area of Economic, Social and Cultural Rights ('Protocol of San Salvador') (17 November 1998) (I-A PESC), entry into force 1999; African Charter on Human and Peoples' Rights (27 June 1981), entry into force 21 October 1986, 1520 UNTS 217 (AfCHPR), Arts 15-18, 21-22; Protocol to the African Charter on Human and Peoples' Rights on the Rights of Women in Africa ('Maputo Protocol') (11 July 2003), entry into force 25 November 2005 (AfCHPR Women's Protocol), passim, in particular Arts 2, 5-7, 10, 12-19; Arab Charter on Human Rights (22 May 2004), entry into force 15 March 2008, reprinted in 12 IHRR 893 (2005) (this is the second iteration of the Arab Charter, which was first adopted in 1994 without any state ratifications), Arts 34-42; Convention on the Elimination of All Forms of Discrimination Against Women (18 December 1979), entry into force 3 September 1981, 1249 UNTS 13 (CEDAW), Arts 10-14; International Convention on the Elimination of All Forms of Racial Discrimination (21 December 1965), entry into force 4 January 1969, 660 UNTS 195 (CERD), Arts 2(2), 3, 5(e); Convention on the Rights of the Child (20 November 1989), entry into force 2 September 1990, 1577 UNTS 3 (CRC), Arts 3, 4, 6, 19 , 23-32, 39; Optional Protocol to the Convention on the Rights of the Child on the Sale of Children, Child Prostitution and Child Pornography (25 May 2000), entry into force 18 January 2002, 2171 UNTS 227 (CRC Protocol 1); Optional Protocol to the Convention on the Rights of the Child on the Involvement of Children in Armed Conflict (25 May 2000), entry into force 12 February 2002, 2173 UNTS 222 (CRC Protocol 2); Convention on the Rights of Persons with Disabilities (13 December 2006), entry into force 3 May 2008, 2515 UNTS 3 (CRPD), Arts. 4(2), 9, 19, 20, 23-28, 30; European Social Charter (revised) (3 May 1996), entry into force 1 July 1999, CETS No 163 (ESC); Inter-American Convention on the Elimination of All Forms of Discrimination against Persons with Disabilities (7 June 1999), entry into force 14 September 2001, AG/RES 1608 (XXIX-O/99) (CIADDIS), Arts II-IV; International Covenant 
The European Social Charter, uniquely among these instruments, contains express provisions limiting applicability to the metropolitan territory of state parties unless states make declarations extending the obligations to their colonies, which none have done. ${ }^{34}$ By contrast, all the other treaties contain provisions relative to applicability which are on their face ambiguous when it comes to the general approach taken within each treaty to the question of whether or not they apply only territorially, or also extraterritorially. ${ }^{35}$

The ICESCR entered into force in 1976 and discussions of its content and meaning in general only started to develop in the following decade, an associated Committee tasked with addressing this and monitoring implementation being established in $1985 .{ }^{36}$ Reflecting a common approach across human rights treaties generally, the predominant and sometimes exclusive focus of discussion of its meaning was in the territorial context, not also considering whether it had an extraterritorial dimension and, if so, whether it might somehow speak to the issue of global economic redistribution as a means of enhancing the realization of social rights internationally. ${ }^{37}$ Thus attention on that issue initially continued to focus exclusively on the foregoing 'soft law' normative regimes.

The AfCHPR entered into force in 1986 and its Women's Rights Protocol in 2005; the associated Commission became operational in the following year, and the associated Court became operational in $2006 .{ }^{38}$ The I-A PESC entered into force in 1999, linked to the preexisting enforcement modalities of the Inter-American human rights system. ${ }^{39}$ The Inter-American CIADDIS entered into force in 2001; its enforcement modality, the Inter-American Committee for the Elimination of All Forms of Discrimination against Persons with Disabilities (CEDDIS), first met in 2007. ${ }^{40}$ The regional specificity of these two sets of arrangements, and the absence of the US from being a party to the Inter-American instruments in particular, has limited their significance to the question of economic redistribution from economically privileged countries to enable the greater realization of social rights of people in economically underprivileged countries, given the absence of most countries in the relatively privileged bracket from the state parties and therefore from being obligation bearers under them. ${ }^{41}$

on Economic, Social and Cultural Rights (16 December 1966), entry into force 3 January 1976, 993 UNTS 3 (ICESCR), passim.

${ }_{34}$ ESC (n 33), Article L. For the declarations made under the Charter see <www.coe.int/en/web/ conventions/full-list/-/conventions/treaty/163/declarations?p_auth=kSgXEOxH $>$ (29 November 2019).

35 Setting aside some of the specific provisions in some of these regimes which are relatively less ambiguous, e.g., references to Trust Territories. See below, $\mathrm{n} 76$.

${ }_{36}$ On the entry into force, see above, $\mathrm{n} 33$. On the Committee, including its establishment, see $<w w w$ .ohchr.org/en/hrbodies/cescr/pages/cescrindex.aspx> (29 November 2019).

37 See, e.g., Matthew Craven, The International Covenant on Economic, Social and Cultural Rights (1998).

38 On the entry into force of both instruments see above, n 33. On the Commission's date of commencing operation, see <www.achpr.org/history> (29 November 2019). On the Court's date of commencing operation, see $<$ https://en.wikipedia.org/wiki/African_Court_on_Human_and_Peoples \%27_Rights> (29 November 2019) (this information is not provided on the official Court website).

${ }^{39}$ On the entry into force, see above, n 34 . On the link to existing systems of enforcement, see IA-PESC (n 33), Art 19.

40 On the entry into force, see above, $\mathrm{n} 33$. On the CEDDIS, see $<$ www.oas.org/es/sedi/ddse/paginas/ index-4_comite.asp> (29 November 2019).

${ }_{41}$ For the parties to the two instruments, see I-A PESC, <www.oas.org/juridico/english/sigs/a -52.html> (29 November 2019); CIADDIS, <www.oas.org/juridico/spanish/firmas/a-65.html> (29 November 2019). 
The Arab Charter has greater potential here, given that some of the parties to it are in the economically privileged bracket - such as Bahrain, Kuwait, Saudi Arabia, Qatar and the UAE - although again the specificity of the regime to Arab countries limits its scope in terms of potential beneficiaries, and more generally the instrument has not been in force relatively long and does not yet have an enforcement mechanism operating to interpret and enforce the meaning of its provisions. ${ }^{42}$

CERD entered into force in 1969, with its enforcement modality, the CERD Committee, beginning its work in $1986 .{ }^{43}$ CEDAW entered into force in 1981, with its enforcement modality, the CEDAW Committee, becoming operational in $1982 .{ }^{44}$ The CRC entered into force in 1990 and Protocols 1 and 2 in 2002, and its enforcement modality, the CRC Committee, became operational in 1991, but the (third) Protocol enabling individual complaints to the Committee did not enter into force until 2014. ${ }^{45}$ The CRPD entered into force in 2008 and its enforcement modality, the CRPD Committee, became operational in $2009 .{ }^{46}$

Overall, the foregoing indicates that in general, and notwithstanding when the ICESCR was adopted, the significance of binding treaty obligations and the operation of associated enforcement mechanisms in the field of economic, social and cultural rights is more recent compared to such obligations and mechanisms in the field of civil and political rights. Notable features of the latter arrangements are the adoption/activation dates of the original instruments and mechanisms associated with the Organization of American States and the Council of Europe, as well as the International Covenant on Civil and Political Rights (ICCPR) and activities of the associated Human Rights Committee, and also the relatively greater enforcement of civil and political rights, including when the operative legal norms are linked to/based on international legal obligations, before domestic courts. These relative differences overall have meant that opportunities to explore the extraterritorial potential of civil and political rights has been considerably greater than in the case of economic, social and cultural rights as a matter of international law.

The key instruments exclusively concerned with civil and political rights similarly contain provisions relative to the question of applicability - chiefly, the term 'jurisdiction' - which are ambiguous on the question of whether or not they apply extraterritorially, but unlike in case of the relevant treaties covering economic, social and cultural rights, the potential for these

42 It has not been possible to find authoritative information about the parties to the Charter. The details mentioned have been taken from Wikipedia, <https://en.wikipedia.org/wiki/Arab_Charter_on _Human_Rights\#cite_note-4> (29 November 2019). As for enforcement, again according to Wikipedia, a Statute for a Court was adopted in 2014, and enters into force after seven ratifications; Saudi Arabia ratified it in 2016. <https://en.wikipedia.org/wiki/Arab_Charter_on_Human_Rights\#cite_note-4> (29 November 2019).

43 On the beginning of the work of the Committee, see Patrick Thornberry, The International Convention on the Elimination of All Forms of Racial Discrimination: A Commentary (2016) 44, text accompanying note 105 , and source cited therein.

44 On the entry into force of CEDAW see above, n 33. On the Committee's establishment, see $<$ www .un.org/womenwatch/daw/cedaw/committee.htm $>$ (29 November 2019).

45 On the CRC Committee's operation from 1991, see <www.ohchr.org/Documents/Publications/ FactSheet10rev.1en.pdf $>$ (29 November 2019). For the third Optional Protocol, see Optional Protocol to the Convention on the Rights of the Child on a Communications Procedure (14 July 2011), entry into force 14 April 2014, UN Doc A/RES/66/138 (CRC Protocol 3).

46 On the date of the Committee becoming operational, see $<$ https://en.wikipedia.org/wiki/Committee _on_the_Rights_of_Persons_with_Disabilities> (29 November 2019). 
ambiguous provisions to have an extraterritorial meaning has been subject to extensive judicial and academic exploration and, as it turns out, affirmation. ${ }^{47}$ Moreover, five broader factors and developments have mediated the way the relative significance of the two sets of rights have been perceived, all in the direction of prioritizing civil and political rights over economic, social and cultural rights. In the first place is the tendency to adopt an exclusively territorial approach when economic, social and cultural rights have been interpreted. In the second place is the popular idea of equating the term 'human rights' more or even exclusively with civil and political rights and private property rights, and therefore seeing it as somehow 'other' than an agenda concerned with socio-economic solidarity to promote social/welfare rights, whether nationally or globally (as is the case in some countries in the west when that term is used). In the third place is the aforementioned failure of the NIEO initiative of economic redistribution as a means of promoting social rights in the Global South. In the fourth place, relatedly, are the 'soft law' normative limitations of the foregoing non-treaty regimes aimed at promoting social rights and the contrasting binding nature of legal regimes concerning trade, finance, development 'aid', investment and intellectual property protection which have been criticized for having had such a negative effect on these rights. Finally, in fifth place, is the actuality of continued extreme poverty, global socio-economic inequality and economic flows from the poor to the rich parts of the world. These factors have led many to criticize or turn away from the global human rights agenda as a legitimate and useful forum within which to articulate claims challenging global socio-economic inequality and promote the social rights of the global poor through ideas of duties owed by the globally economically privileged. ${ }^{48}$

However, relatively recently, there has been a shift in focus to affirm the extraterritorial application of human rights obligations in the area of economic, social and cultural rights. This has come through important affirmations by the Committee on Economic, Social and Cultural Rights (CESCR), to be addressed below. It is also reflected in the 2001 adoption by a group of experts of the 'Maastricht Principles' on the subject, together with an associated commentary and broader supportive academic literature. ${ }^{49}$ Moreover, when the International Court of Justice (ICJ), as part of its general shift into the enforcement of international human rights law, affirmed the extraterritorial application of this law, it did so in a manner that covered both economic, social and cultural rights as well as civil and political rights, reflecting how, as a body with potentially plenary reach when it comes to applicable law, it was able to move beyond the limitations of human rights enforcement bodies tied to particular treaty instruments, and

47 See the discussion and sources cited in Ralph Wilde, 'The Extraterritorial Application of International Human Rights Law on Civil and Political Rights' in Scott Sheeran and Nigel Rodley (eds), Routledge Handbook of International Human Rights Law (2013) chapter 35.

48 E.g., most recently, Samuel Moyn, Not Enough: Human Rights in an Unequal World (2018); contrast this with the position of Chimni (n 6), discussed below in Section V.

49 The Maastricht Principles on the Extraterritorial Obligations of States in the Area of Economic, Social and Cultural Rights (ETO Consortium 2011) <www.maastrichtuniversity.nl/web/Institutes/ MaastrichtCentreForHumanRights/MaastrichtETOPrinciples.htm> (29 November 2019); Olivier De Schutter et al, 'Commentary to the Maastricht Principles on Extraterritorial Obligations of States in the Area of Economic, Social and Cultural Rights' (2012) 34 HRQ 1084. For a critical analysis of the general topic and the Maastricht initiative, plus further references relating to it see, e.g., Wilde (n 20), and sources cited therein. 
the bias in favour of civil and political rights reinforced by the relatively greater activity by institutional arrangements focusing on that field. ${ }^{50}$

Moreover, there has also been a relatively recent acceptance that human rights obligations concerning the environment have an extraterritorial dimension, notably with the landmark 2018 Advisory Opinion of the Inter-American Court of Human Rights on the American Convention on Human Rights, covering civil and political rights, which, following the established position that the term 'jurisdiction' in that treaty has an extraterritorial dimension, affirmed the applicability of transboundary environmental harm in a manner that builds on the regime in international environmental law reflected in the aforementioned principle 2 of the Rio Declaration. ${ }^{51}$ As indicated by this Opinion, and by other human rights jurisprudence on the environment generally, human rights law is also significant to the 'environmental justice' topic because of the greater opportunities for enforcement/adjudication that its associated bodies provide compared to the picture when international environmental law is addressed in isolation. ${ }^{52}$

That said, the extraterritorial application of all human rights law - relating to civil and political rights as well as economic, social and cultural rights - remains a hugely contested matter. In the field of economic, social and cultural rights in particular, the question of whether or not such applicability - and, within it, binding obligations that might speak to questions of economic redistribution within the terminology of 'cooperation' and 'assistance' used in some of the aforementioned treaties (to be explored below) - is settled law or merely at the stage of de lege ferenda remains disputed, as reflected, for example, by the manner in which the Maastricht Principles advocates hedge their position on the latter issue, seemingly out of deference to resistance by socio-economically privileged states. ${ }^{53}$ The Maastricht initiative notwithstanding, commentary on extraterritorial applicability remains skewed towards coverage of civil and political rights, and, the determinations by the CESCR and the jurisprudence of the ICJ notwithstanding, international enforcement remains similarly skewed.

Human rights treaty law may have potential for the question of global economic redistribution to promote social rights via extraterritorial obligations, then, but whether this amounts to much remains unclear. Moreover, when it comes to the 'environmental justice' topic in particular, whereas the concept of extraterritorial human rights obligations triggered in circumstances of transboundary environmental harm, as addressed in the Inter-American Advisory Opinion, is obviously of direct significance and thus central importance, attention is also needed on the potential that the separate, more general notion of social rights obligations operating across borders might also have for the topic. ${ }^{54}$

Thus far, there has not been a detailed and comprehensive academic treatment of all the relevant treaty provisions on the question of extraterritoriality and social rights, expert commentary tending to either ignore or downplay socio-economic rights or, when addressing them, to be selective, focusing only on the ICESCR or only on the global instruments, or not

50 See Ralph Wilde, 'Human Rights Beyond Borders at the World Court: The Significance of the International Court of Justice's Jurisprudence on the Extraterritorial Application of International Human Rights Law Treaties' (2013) 12 Chinese Journal of International Law 639, and sources cited therein.

51 IACtHR, Advisory Opinion OC-23/17 (n 32), paras 72-82, 95-103.

52 On this jurisprudence, see the sources cited above, note 31.

53 See the discussion and sources cited in Wilde (n 20), 161-64, 167-68, 171-75.

54 For discussion of the broader potential relevance of human rights generally, see e.g. Shelton (n 9), section E. 
addressing detailed treaty provisions. ${ }^{55}$ This is unfortunate in many respects, not least because, when it comes to enforcement and other means of authoritative interpretations, modalities such as those reviewed above are often linked to particular instruments, and expert analysis is of little/no use if it is either too generic (especially if what counts for generic analysis is actually based on a highly selective review of relevant instruments) or, when it is specific, omits particular instruments, thereby failing to be of any assistance when such instruments come to be interpreted.

As a means of redressing this, the present chapter provides a detailed and comprehensive analysis of the extraterritoriality question, focusing on economic transfers, when it comes to the provisions of all the aforementioned treaties - with the exception of the European Social Charter, given the seemingly settled position indicated above on its exclusively metropolitan territory application, absent express extensions being made to colonial territories. ${ }^{56}$ This analysis explores whether or not the provisions are capable of providing a basis for binding obligations that operate extraterritorially. The focus is concerned primarily with the potential these provisions might suggest. The few instances where this potential has been clearly realized through authoritative determinations (such as by the ICJ) are referenced, but given the scant jurisprudence here, the analysis is as much about what interpretive options exist. This is done by focusing on what the treaties say, if anything, about where the obligations they contain apply, and how this question of applicability has been interpreted, and then the potential implications of the foregoing for the question of extraterritorial applicability.

The relevant human rights treaties contain express stipulations of their core obligations that vary significantly, in a highly complex manner, when it comes to the implications for spatial applicability. The following sections review these treaty provisions, mapping out an interpretative taxonomy of extraterritorial applicability. This begins, in section II, by reviewing how most of the relevant treaties link their obligations to secure economic, social and cultural rights to international assistance/cooperation/collaboration/relations. This is significant for the general approaches the treaties then take to the areas in which the obligations they contain apply. Two such approaches can be identified. In the first place, as reviewed in section III, is a 'free standing' regime of applicability, viz. lacking an express general stipulation as to where the obligations they contain apply. In the second place, as reviewed in section IV, is a regime based on such an express general stipulation: the term 'jurisdiction'. The extraterritorial potential of these two regimes of applicability is explored in each section, taking into account the significance to this, where relevant, of the links made to international cooperation, etc. These two approaches to applicability do not neatly correspond to particular treaty regimes in a mutually exclusive fashion: some treaty regimes encapsulate both as a general matter; others encapsulate one as a general matter and the other in relation to specific rights.

55 See, e.g., Sigrun Skogly, Beyond National Borders: States' Human Rights Obligations in International Cooperation (2006); Michał Gondek, The Reach of Human Rights in a Globalising World: Extraterritorial Application of Human Rights Treaties (2009).

56 This is not to accept that the seemingly settled position is, in the final analysis, correct. Space limitations prevent that question from being explored in the present piece. 


\section{GENERAL FACTOR: REFERENCES TO INTERNATIONAL ASSISTANCE AND/OR COOPERATION AND/OR COLLABORATION AND/OR RELATIONS}

In considering the extraterritorial potential of the different regimes of applicability in the relevant treaties, it is necessary to begin by identifying a general context referred to in many of these regimes: international assistance and/or cooperation/collaboration/relations. This context is invoked as a framework within which economic, social and cultural rights should be realized.

Under the ICESCR, the general obligation (reviewed further below) to 'take steps' to realize the rights in the treaty is to be performed 'individually and through international assistance and co-operation' ${ }^{57}$ This requirement is then repeated with respect to various specific provisions in the Covenant. ${ }^{58}$ The Covenant also stipulates that parties agree on the need for 'international action for the achievement of the rights' which it contains, with a non-exhaustive list of examples which include providing technical assistance. ${ }^{59}$

Similarly, the I-A PESC references the 'benefits that stem from the promotion and development of cooperation among States and international relations' in its preamble, and in its general obligation to 'adopt the necessary measures' to bring about the full observance of the rights it contains it stipulates that these should be 'both domestically and through international cooperation'. ${ }^{60}$ International cooperation is also referenced in relation to the particular rights to food and the benefits of culture, the provision on the latter also invoking the significance of international relations. ${ }^{61}$

Also similarly, the CRC references the importance of international cooperation in its preamble (applicable to all the rights it contains, which are civil and political as well as economic, social and cultural in nature), in its main provision on implementing economic, social and cultural rights, and in specific provisions dealing with access to material from mass media, the right to health, the exchange of information on care for children with disabilities and matters relating to education. ${ }^{62}$ It also references the importance of "co-operation in any efforts by the United Nations and other competent intergovernmental organizations or non-governmental organizations co-operating with the United Nations' relating to refugee protection. ${ }^{63} \mathrm{CRC}$ Protocol 1, concerned with suppressing child prostitution and pornography, includes provisions on international cooperation regarding the 'root causes, such as poverty and underdevelopment', contributing to the vulnerability of children, and requiring states 'in a position to do' so to engage in international cooperation and assistance with regard to suppression activities generally, including cooperation on addressing root causes. ${ }^{64} \mathrm{CRC}$ Protocol 2, concerned with protecting children from involvement in armed conflict, similarly obliges states to engage in international cooperation and assistance generally on the implementation of the Protocol, and

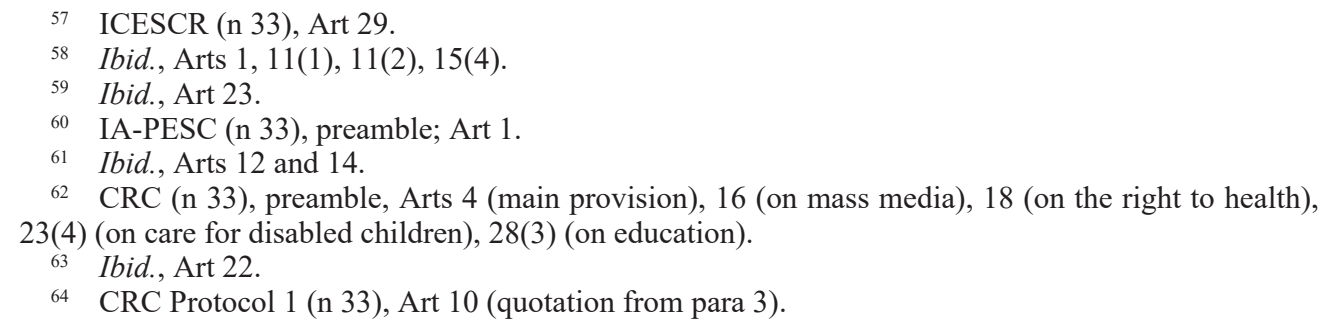


in particular requires that states 'in a position to do so' engage in the provision of financial assistance in this regard. ${ }^{65}$

The CRPD emphasizes in its preamble the importance of cooperation in relation to improving the living conditions of persons with disabilities, and invokes cooperation in its dedicated article on economic, social and cultural rights. Also, it has a separate, dedicated article on 'the importance of international cooperation and its promotion', providing stipulations on how this should be conducted, and, further, makes the consideration of international cooperation, and transmitting to international bodies requests for advice and assistance by state parties, part of the mandate of the Committee set up to scrutinize the implementation of the Convention. ${ }^{66}$

Like the CRPD, CIADDIS has an article specifically addressing cooperation, in this case articulated in terms of action between state parties in the prevention and elimination of discrimination against persons with disabilities, and also in undertaking to collaborate in both relevant research and developing means and resources to promote the independence, self-sufficiency, and total integration into society' of persons with disabilities. ${ }^{67}$

The provisions on economic, social and cultural rights in the AfCHPR, its Protocol on Women's Rights, CEDAW, CERD and the Arab Charter do not generally reference international cooperation in the realization of these specific rights. ${ }^{68}$ However, the AfCHPR, CEDAW and the Arab Charter do contain some references to international cooperation. In the case of the ACfHPR, its preamble references the pledge in the preamble to the OAU Charter, and in the UN Charter and the UDHR, to cooperate in the socio-economic field; the article on self-determination references the right of peoples to assistance in liberation struggles; and the article on the right to freely dispose of wealth and resources also references the obligation of economic cooperation. ${ }^{69}$ In the case of CEDAW, the Preamble references the importance of international cooperation in promoting social progress and development. ${ }^{70}$ In the case of the Arab Charter, it contains an important provision affirming the right to development, which also references international cooperation:

all States $[\ldots]$ have a duty to give effect to the values of solidarity and cooperation among them and at the international level with a view to eradicating poverty and achieving economic, social, cultural and political development. By virtue of this right, every citizen has the right to participate in the realization of development and to enjoy the benefits and fruits thereof. ${ }^{71}$

Its provision on culture and science also references cooperation. ${ }^{72}$

All the foregoing provisions on assistance and cooperation provide a general context for the substantive obligations that the treaties contain when it comes to the realization of the rights they contain. The significance of the provisions will be revisited, then, when these obligations

CRC Protocol 2 (n 33), Art 7 (quotation from para 2).

${ }_{66}$ CRPD (n 33), preamble, Arts 4(2) (on economic, social and cultural rights), 32 (dedicated article on cooperation), 36(5) and 37(2) (mandate of the Committee).

67 CIADDIS (n 33), Art IV.

68 For these provisions, see the references above, $\mathrm{n} 33$.

${ }_{69}$ AfCHPR (n 33), preamble, Arts 20(3) and 21(3). The relevant provisions of the OAU Charter (Charter of the Organization of African Unity (25 May 1963) 479 UNTS 39), are the preamble and Arts 1 and 2.

70 CEDAW (n 33), preamble.

71 Arab Charter (n 33), Art 37.

72 Ibid., Art 42(3). 
are reviewed. This is done in the following two Sections, III and IV. Attention now turns, in Section III, to the first of the two general regimes of applicability, the 'free standing' approach to obligations.

\section{FREE STANDING APPROACH TO APPLICABILITY, INCLUDING 'TAKE STEPS' - AFCHPR AND ITS PROTOCOL ON THE RIGHTS OF WOMEN, CEDAW, CERD, CIADDIS, CRPD, I-A PESC, ICESCR}

\section{a. As Evident in the Treaties}

The AfCHPR and its Protocol on the Rights of Women, CEDAW, CERD, CIADDIS, the CRPD, the I-A PESC and the ICESCR adopt a 'free standing' model of applicability in general: they lack an express general stipulation about where the obligations to secure the individual/group rights (and obligations, in the case of the AfCHPR) contained within them apply (although in some cases, as will be explained, such a stipulation is given in relation to particular rights). They either contain a general clause (the ICESCR and AfCHPR) or a series of general clauses (the CRPD, the I-A PESC) setting out the nature of the obligations to secure such rights (and obligations in the AfCHPR) which lack an indication in this regard (such as by referring to 'jurisdiction'), or they lack such a general clause, obligations being stipulated in particular provisions which themselves (with some exceptions, as will be explained) lack an indication in this regard (the AfCHPR Protocol on Women's Rights, CEDAW, CERD and CIADDIS). ${ }^{73}$

The general clause of the ICESCR is articulated as follows:

Each State Party to the present Covenant undertakes to take steps, individually and through international assistance and co-operation, especially economic and technical, to the maximum of its available resources, with a view to achieving progressively the full realization of the rights recognized in the present Covenant by all appropriate means, including particularly the adoption of legislative

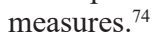

73 The AfCHPR (n 33) states in Article 1 that ' $[\mathrm{t}]$ he [...] parties to the present Charter shall recognise the rights, duties and freedoms enshrined in the Charter and shall undertake to adopt legislative or other measures to give effect to them'. But see below (n 75) for a reference to 'territory' in relation to one particular right. Under the CRPD (n 33), state parties 'undertake to ensure and promote the full realization of all human rights and fundamental freedoms for all persons with disabilities without discrimination of any kind on the basis of disability' (Art 4(1)). It then stipulates a series of general undertakings, all of which similarly make no reference to where they apply, for example ' $[t]$ o adopt all appropriate legislative, administrative and other measures for the implementation of the rights recognized in the present Convention' (Art 4(1)(a)). See also the general clause relating to economic, social and cultural rights extracted in the text accompanying the following footnote. For the I-A PESC (n 33), the general obligations are contained in Arts 1-5; the main clause, in Art 1, is extracted below, $\mathrm{n} 74$. For the AfCHPR Protocol on Women's Rights, CEDAW, CERD and CIADDIS (all n 33), there is no specific article stipulating a general regime of obligations in the treaty; the 'free standing' approach is evident in each of the specific obligations across the instruments (other than in particular instances, addressed herein).

74 ICESCR (n 33), Art 2(1). 
This language is echoed in the I-A PESC, and the particular general clause of the CRPD which deals with economic, social and cultural rights (that treaty, unlike the ICESCR and the I-A PESC, is not specific to such rights). The key differences for present purposes are that instead of taking 'steps' these treaties refer to taking 'measures', and that they only refer to taking action 'through' or 'within the framework of' 'international cooperation', not also assistance. ${ }^{75}$

Some of these instruments contain provisions on particular rights/aspects of rights that are specific to spatially defined contexts (such as 'jurisdiction' or 'territory'). ${ }^{76} \mathrm{~A}$ treatment of these provisions is beyond the scope of the present piece - apart from one specific provision, in Article 14 ICESCR, which is relevant, as will be explained below, to the question of the extraterritorial applicability of that treaty in general.

\section{b. Extraterritorial Meaning, Including through the Links to International Cooperation, etc.}

\section{i. The ambiguous significance of the provisions}

These 'free standing' obligations, including obligations to take 'steps'/'measures', which are articulated without any indication of where/in relation to whom the steps/measures are taken, could be limited to the situation within each state's sovereign territory, or could also encompass extraterritorial situations.

As for provisions that reference cooperation and, in the case of the ICESCR, assistance, there are two sets of provisions to be considered here: first, those in the AfCHPR, and second, those in the ICESCR, the I-A PESC and the CRPD. As for the provisions in the AfCHPR, as mentioned, these are the specific provisions on self-determination, which reference the right of peoples to assistance in liberation struggles, and the right to freely dispose of wealth and resources, which references the obligation of economic cooperation. As for the provisions in the ICESCR, the I-A PESC and the CRPD, these are the requirement to take steps/measures to realize economic, social and cultural rights in particular, doing this through/within the framework of 'cooperation' and, in the case of the ICESCR, 'assistance'.

These provisions could refer only to being the beneficiary of cooperative activities and assistance, where it is offered, when addressing the territorial situation. They could also refer to being engaged in the provision of assistance and activities of international cooperation (when in a position to do so) in relation to extraterritorial situations. Whereas clearly engaging

75 I-A PESC (n 33), Art 1 reads:

to adopt the necessary measures, both domestically and through international cooperation, especially economic and technical, to the extent allowed by their available resources, and taking into account their degree of development, for the purpose of achieving progressively and pursuant to their internal legislations, the full observance of the rights recognized in this Protocol.

The somewhat equivalent clause in Art 4(2) CRPD (n 33) reads:

to take measures to the maximum of its available resources and, where needed, within the framework of international cooperation, with a view to achieving progressively the full realization of these rights, without prejudice to those obligations contained in the present Convention that are immediately applicable according to international law.

76 See AfCHPR (n 33), Arts 12(4) and 23(2)(b); AfCHPR Women's Rights Protocol (n 33), Art 10(2); CIADDIS (n 33), Art III(1)(b); ICESCR (n 33), Arts 1, 14; CEDAW (n 33), Arts 3, 6, 14(1), 14(2), 15; IA-PESC (n 33), Art 10(2)(b). 
in the former activities (being a beneficiary) on the part of any given state would presuppose that one or more other states and/or international organizations are engaged in the latter activities (being a provider), rendering the former activity obligatory does not necessarily require the latter also to be obligatory; it could simply require action for the beneficiary state insofar as (as a matter of discretion) action is taken by a provider state/international organization. But equally the provision could be interpreted so that there are obligations both ways. If the latter interpretation were followed, an obligation borne by the provider state would have implications for economic transfers across borders from the socio-economically privileged to the socio-economically less privileged, aimed at the greater realization of social rights for people in the latter category.

Such an interpretation has indeed been followed by the CESCR as far as the ICESCR is concerned, suggesting an extraterritorial orientation, both in a general, non-specific fashion that would be broad enough to encompass an obligation to engage in economic transfers, and even specifically to stipulate an obligation to provide assistance extraterritorially. This approach is potentially transferable to the AfCHPR, I-A PESC and the CRPD.

Similarly, more generally the CERD has been interpreted to have an extraterritorial meaning, an approach that is potentially transferable to the other treaties that also lack general clauses stipulating the nature of the obligations they contain, viz. the AfCHPR Protocol on Women's Rights, CEDAW and CIADDIS.

\section{ii. ICESCR, with transferability to the AfCHPR, CRPD and I-A PESC}

The CESCR has made various pronouncements affirming the extraterritorial application of the free standing obligation in the Covenant. Adopting the tripartite conception of obligations, pronouncements that are specific to 'respecting' and 'protecting' human rights in the extraterritorial context are significant because they are potentially reflective of a general understanding of extraterritorial applicability. Pronouncements on 'fulfilling' rights extraterritorially are significant in this general sense and also more specifically for the present focus on socio-economic redistribution, given that the provision of material assistance is a key element of fulfilling rights.

On the obligation to 'respect', the CESCR has stated that states are obliged under the Covenant 'to take steps to respect the enjoyment of the right to food in other countries' and 'to respect the enjoyment of the right to health in other countries'. ${ }^{77}$ This obligation understood extraterritorially has been most fully explored in the context of economic sanctions, and there is now general consensus that in certain circumstances sanctions which have the effect of diminishing the enjoyment of economic, social and cultural rights in the 'target' state violate the sanctioning state's human rights obligations. ${ }^{78}$ On the right to food in particular, the CESCR stipulated that

77 CESCR, 'General Comment No 12 on the Right to Adequate Food' (12 May 1999) UN Doc E/C.12/1999/5, para 36; CESCR, 'General Comment No 14 on the Right to the Highest Attainable Standard of Health' (11 August 2000) UN Doc E/C.12/2000/4, para 39.

78 See, e.g., CESCR, 'General Comment No 8 on the Relationship between Economic Sanctions and Respect for Economic, Social and Cultural Rights' (12 December 1997) UN Doc E/C.12/1997/8; see also Matthew Craven, 'Human Rights in the Realm of Order: Sanctions and Extraterritoriality' in Fons Coomans and Menno T Kamminga (eds), Extraterritorial Application of Human Rights Treaties (2004) 233. 
States parties should refrain at all times from food embargoes or similar measures which endanger conditions for food production and access to food in other countries. Food should never be used as an instrument of political and economic pressure. ${ }^{79}$

On the right to health in particular, the CESCR stipulated that

States parties should refrain at all times from imposing embargoes or similar measures restricting the supply of another State with adequate medicines and medical equipment. Restrictions on such goods should never be used as an instrument of political and economic pressure. ${ }^{80}$

On the obligation to 'protect', when it comes to the right to health in particular, the CESCR has stated that state parties to the ICESCR must

prevent third parties from violating the right in other countries, if they [states parties] are able to influence these third parties by way of legal or political means, in accordance with the Charter of the United Nations and applicable international law. ${ }^{81}$

When it comes to the 'right to food in other countries' in particular, the Committee has stated that states have an obligation under the Covenant to 'take steps to protect that right' ${ }^{82}$

Whereas the foregoing specific determinations can be seen as reflective of a more general position on extraterritorial applicability which might also encompass a specific obligation concerning economic redistribution, it is the obligation to 'fulfil' rights which has the potential to implicate such a specific obligation directly. This potential would seem to be realized through determinations affirming that the obligation of cooperation includes a requirement to provide assistance to other states. In its General Comment No 3, the CESCR stated that, as a matter of the ICESCR and other norms,

international cooperation for development and thus for the realization of economic, social and cultural rights is an obligation of all States. It is particularly incumbent upon those States which are in a position to assist others in this regard. ${ }^{83}$

\section{Moreover,}

in the absence of an active programme of international assistance and cooperation on the part of all those States that are in a position to undertake one, the full realization of economic, social and cultural rights will remain an unfulfilled aspiration in many countries. ${ }^{84}$

On the right to food 'in other countries' in particular, the Committee stated in General Comment No 12 that states 'should take steps to facilitate access to food and to provide

CESCR (GC 12) (n 77), para 37.

CESCR (GC 14) (n 77), para 41.

Ibid., para 39.

CESCR (GC 12) (n 77), para 36.

83 CESCR, 'General Comment No 3 on the Nature of States Parties' Obligations' (14 December 1990) UN Doc E/1991/23, para 14.

84 Ibid., para 13. 
the necessary aid when required' ${ }^{85}$ On the right to health, the Committee stated in General Comment No 14 that

[d]epending on the availability of resources, States should facilitate access to essential health facilities, goods and services in other countries, wherever possible, and provide the necessary aid when required. ${ }^{86}$

This assertion is then linked, via a footnote, to the following assertion made later in the same General Comment:

For the avoidance of any doubt, the Committee wishes to emphasize that it is particularly incumbent on States parties and other actors in a position to assist, to provide 'international assistance and cooperation, especially economic and technical' [a quote from the Covenant, Art. 2.1] which enable[s] developing countries to fulfil their core and other obligations [regarding the right to health] ${ }^{87}$

This builds on the earlier statement on the negative consequences of there being an absence of assistance programmes on the part of states with the relevant material capacities, creating a positive assertion of a requirement to provide assistance on the part of such states, a position reinforced by the assertion made in relation to the right to food in General Comment No 12 . A further assertion has been made in the specific context of emergencies, thus:

States parties have a joint and individual responsibility, in accordance with the Charter of the United Nations and relevant resolutions of the United Nations General Assembly and of the World Health Assembly, to cooperate in providing disaster relief and humanitarian assistance in times of emergency, including assistance to refugees and internally displaced persons. Each State should contribute to this task to the maximum of its capacities. ${ }^{88}$

There is also a specific 'collective responsibility to address' the problem of diseases that are easily transmissible across borders, and 'economically developed States [...] have a special responsibility and interest to assist the poorer developing States in this regard' ${ }^{89}$

Taking these statements together, there is clear authority that the Covenant applies extraterritorially in general, and in particular the obligation to 'take steps [...] through international assistance and co-operation' includes the provision of assistance extraterritorially on the part of states in a material position to do so.

The Committee has also made various stipulations concerning what should be done in terms of how assistance programmes operate and the impact of this on the human rights in the Covenant generally; how assistance programmes in the context of emergencies should operate; and the impact of international agreements, and the actions of international organizations, notably the international financial institutions, on the right to health in particular. ${ }^{90}$ These

\footnotetext{
85 CESCR (GC 12) (n 77), para 36.

86 CESCR (GC 14) (n 77), para 39 (footnote omitted).

87 Ibid., para 45.

88 Ibid., para 40.

89 Ibid., para 40. This stipulation is prefaced by the observation that 'given that some diseases are easily transmissible beyond the frontiers of a State'. Such a rationale does not rule out the co-application of other normative underpinnings, including that which is the subject of the present focus.

90 See, e.g., CESCR, 'General Comment No 2 on International Technical Assistance Measures' (2 February 1990) UN Doc E/1990/23 on assistance programmes on the rights in the Covenant generally; CESCR (GC 14) (n 77), on assistance in the context of emergencies; ibid., para 40, on the right to health.
} 
stipulations imply the extraterritorial application of the Covenant in general, building on what has already been reviewed in this regard..$^{11}$

The approach to extraterritorial applicability generally taken for the ICESCR is transferable to the other treaties that contain equivalent provisions: to the AfCHPR, which similarly contains a general free standing clause setting out the nature of its obligations (and rights) generally, and to the CRPD and the I-A PESC, which contain a series of general clauses setting out the nature of the obligations to secure rights therein.

When it comes to the specific obligation to take 'measures' 'through international co-operation' with respect to economic, social and cultural rights in the CRPD and I-A PESC, and the obligation to engage in economic cooperation when it comes to the right to freely dispose of wealth and resources in the AfCHPR, the absence of the word 'assistance' sets the provisions apart from the ICESCR obligation to take 'steps [...] through international assistance and co-operation'. This potentially rules out the transferability of the aforementioned approach taken by the CESCR - that this provision amounts to an obligation on the part of states in a position to do so to provide economic assistance across borders. However, 'assistance' can be seen as encompassed within 'cooperation' so as to enable this. In any case, the approach taken to 'assistance' under the ICESCR is potentially transferable to the express reference to this term in the AfCHPR when it comes to the rights of peoples to assistance in liberation struggles.

\section{iii. CERD, with transferability to the AfCHPR Protocol on Women's Rights, CEDAW and CIADDIS}

As for CERD, in the 2008 Provisional Measures Order in the Georgia v Russia case, the ICJ observed

that there is no restriction of a general nature in CERD relating to its territorial application; whereas it further notes that, in particular, neither Article 2 nor Article 5 of CERD, alleged violations of which [by Russia in Georgia] are invoked by Georgia, contain a specific territorial limitation [...] the Court consequently finds that these provisions of CERD generally appear to apply, like other provisions of instruments of that nature, to the actions of a State party when it acts beyond its territory. ${ }^{92}$

It then went on to call upon '[b]oth Parties, within South Ossetia and Abkhazia and adjacent areas in Georgia' to take certain acts to comply with the Convention, a determination that assumed the extraterritorial application of CERD to Russian forces in Georgia. ${ }^{93}$

In the Roma Rights decision of the UK's highest court, then called the Judicial Committee of the House of Lords, it was held that CERD applied extraterritorially to the actions of UK immigration officials in Prague airport. This was done without explanation, assuming applicability when holding that the actions at issue breached the treaty. ${ }^{94}$

91 In being specific to how assistance programmes are conducted and the impact of the actions of international financial institutions are not by themselves authority for the proposition that there is a particular extraterritorial obligation to provide assistance.

92 Application of the International Convention on the Elimination of all Forms of Racial Discrimination (Georgia v Russian Federation) 2008 ICJ 353, para 109 (Provisional Measures of 15 October).

$93 \quad$ Ibid., para 149.

94 $R$ v Immigration Officer at Prague Airport and another (Respondents) ex parte European Roma Rights Centre and others (Appellants), 9 December 2004, [2004] UKHL 55. Lady Hale holds that the 
In its 2019 decision on preliminary objections in the Ukraine $v$ Russia case, the ICJ took the same approach as the Judicial Committee of the House of Lords, assuming extraterritorial applicability without explanation. It held that the complaints Ukraine was making, concerning violations by Russia of the CERD, fell within the provisions of the treaty. ${ }^{95}$ These complaints covered, inter alia, the situation in Crimea, which Ukraine and many other states and independent international legal experts regard to be Russian-occupied Ukrainian territory, and Russia regards to be its own territory. The Court did not take an express position on the legal status of the territory, nor did it expressly address the issue of territorial/extraterritorial applicability of the Convention. That said, on the legal status issue, it is somewhat unlikely that on such an important matter the Court would opt for implying a position in favour of one view over the other, in lieu of making an express statement on the matter and providing justification for the position taken. Given this, it is preferable to view the Court's position on the complaints falling within the scope of the Convention as intended to be without prejudice to the question of the status of the territory being determined. As such, this position has to assume that the Convention is capable of applying not only territorially but also extraterritorially (if extraterritorial applicability was not being assumed, then the Court's finding would have to be based on an assumption that Crimea was Russian territory).

This approach to CERD is potentially transferable to the other treaties which similarly lack general causes on the nature of the obligations they contain, obligations instead being stipulated in particular provisions which themselves lack an indication in this regard: the AfCHPR Protocol on Women's Rights, CEDAW and CIADDIS.

\section{c. Potential for Socio-economic, Colonial and Environmental Justice Across Borders}

The relevance of the foregoing analysis to the idea of economic transfers from the economically privileged to secure social rights across borders is that this can be understood as a multi-level regime cascading through progressive specificity. At the most general level there is simply an extraterritorial orientation to realize socio-economic obligations, within which is the potential, among many other things, for states with the means to engage in resource transfers across borders to secure social rights. This operates with respect to all the instruments: the AfCHPR and its Protocol on the Rights of Women, CEDAW, CERD, CIADDIS,

practice "was not only unlawful in domestic law but also contrary to our obligations under customary international law and under international treaties to which the United Kingdom is a party' (para 98). She then goes on to review CERD as one such treaty in paras 100-101. Lords Bingham, Carswell and Hope agree with Lady Hale's general finding on discrimination, thereby including the position on applicability she assumes within this (paras 31 [implicitly], 106 and 114 [with a qualification that is not material to the applicability question], and 48 respectively). Lord Steyn quotes the relevant provisions from CERD and asserts that " $[\mathrm{t}]$ he operation at Prague Airport placed the United Kingdom in breach of this international obligation' (para 44). He also offers his agreement to the 'reasons given by Baroness Hale on the discrimination issue' (para 47). This amounts to a unanimous position in the decision in favour of a seemingly automatic applicability of CERD to UK officials acting extraterritorially, given in the context of the immigration decisions being made by such officials, but not explained as being specific to that in terms of its rationale (since no rationale is considered - applicability is assumed).

95 Application of the International Convention for the Suppression of the Financing of Terrorism and of the International Convention on the Elimination of All Forms of Racial Discrimination (Ukraine $v$ Russian Federation) (Preliminary Objections) 2019 ICJ paras 95-97 (Judgment of 8 November 2019). 
CRPD, I-A PESC and the ICESCR. Then there is a relatively narrower obligation to engage in international cooperation in the realization of socio-economic rights extraterritorially, again within which is the potential for a requirement for states with the means to engage in resource transfers across borders. This operates with respect to socio-economic rights in a general sense as a matter of the ICESCR, the CRPD and I-A PESC, and the right to freely dispose of wealth and resources under the AfCHPR. Then, even more narrowly, there is a specific obligation to engage in assistance in the realization of socio-economic rights extraterritorially, which has been affirmed to include the provision of economic assistance across borders by states with the means to do this as far as the ICESCR is concerned - an approach that is potentially transferable to the obligation to assist peoples in liberation struggles under the AfCHPR.

An obligation borne by states to realize social rights extraterritorially has the potential to provide one way through which the agenda of global socio-economic, colonial and environmental justice can be realized, via economic transfers across borders, for the following reasons. In the first place, the extraterritorial orientation is general, thereby taking in all people in the world. In the second place, the way in which obligations to realize social rights are conceived in terms of the position of the rights-holders - that those in greatest need should be given the greatest support - incorporates the objective of challenging inequality in the way that it operates. Similarly, the way such obligations are conceived in terms of the position of the obligation-bearers - that the level of support should be set depending on available resources - incorporates the objective that the globally economically privileged should bear a greater substantive requirement when it comes to the level of resources provided.

Getting to the stage of such a normative regime would require many further steps. Before reviewing what would be needed here, attention will turn to the alternative basis for extraterritorial human rights obligations in human rights treaties, the ‘jurisdiction' concept.

\section{IV. 'JURISDICTION' - ARAB CHARTER, CRC, CRC PROTOCOLS 1 AND 2, READ INTO THE ICESCR AND AFCHPR, AND IN CONSEQUENCE POTENTIALLY RELEVANT TO OTHER TREATIES WITH 'FREE STANDING' CONCEPTIONS OF OBLIGATIONS}

\section{a. Arab Charter, CRC and CRC Protocols 1 and 2 Express Provisions}

The Arab Charter contains a general stipulation whereby states are obliged 'to ensure to all individuals subject to its jurisdiction the right to enjoy the rights and freedoms set forth herein'. ${ }^{96}$ Specific provisions, which do not have direct implications for economic redistribution, also reference (again) 'jurisdiction' or 'territory' as the locus for their operation. ${ }^{97}$ Under the $\mathrm{CRC}$, state parties are obliged to 'respect and ensure' the rights in the treaty to 'each

96 Arab Charter (n 33), Art 3(1).

97 On 'jurisdiction', see ibid., Arts 8 (on the probation on torture, in human and degrading treatment), 12 (on the right to a legal remedy). On 'territory', see ibid., Arts 26 (freedom of movement and the expulsion of individuals from a state's territory) and 34(5) (the rights of migrant workers in a state's territory). 
child within their jurisdiction' - a general clause, like in the Arab Charter. ${ }^{98}$ Under the CRC Protocols 1 and 2, each state party is obliged to 'take all necessary legal, administrative and other measures to ensure the effective implementation and enforcement of the provisions of the present Protocol within its jurisdiction'. ${ }^{99}$

\section{b. Extraterritorial Meaning}

As with the 'free standing' approach to applicability, the term 'jurisdiction' is ambiguous when it comes to its spatial limits. It could be synonymous with the exercise of state authority in its sovereign territory exclusively, or also have an extraterritorial dimension.

However, the relatively greater instances of authoritative decisions in the field of civil and political rights when compared to economic, social and cultural rights, problematic as a general matter, are less concerning on this particular issue because of the potential transfer of underlying common ideas between the two normative regimes. This is possible because the key treaties on civil and political rights - the American Convention on Human Rights, the European Convention on Human Rights, and the ICCPR - all contain the 'jurisdiction' regime of applicability, and have all been consistently interpreted in such decisions by national and international bodies to have an extraterritorial dimension. ${ }^{100}$

This dimension can be characterized in terms of the existence of a particular type of power relationship between a state and people outside its borders. It has usually been defined somewhat narrowly, to require a degree of kinetic 'effective control' exercised in a direct sense over territory and/or individuals, for example during a military occupation. ${ }^{101}$ Only in such circumstances do the obligations apply, and, indeed, it is because of the exercise of this type of determinative power relationship between a state and people/territory outside its sovereign territory that the obligations are seen as necessary. According to this view, absent this particular power relationship, the obligations are inapplicable.

As might be expected, this approach to the extraterritorial meaning of the term 'jurisdiction' in treaties covering civil and political rights exclusively has also been followed for the CRC and CRC Protocol 2, which cover these rights and also economic, social and cultural rights (in the latter case as far as the provision of international assistance in efforts to protect children from involvement in armed conflict is concerned). The extraterritorial applicability of the CRC has been affirmed by both the CRC Committee and the ICJ, the latter also making such an affirmation in the case of CRC Protocol 2. The affirmation by the Committee is contained, for example, in the way it has assumed the applicability of the CRC to Israel in the occupied Palestinian territories (which are extraterritorial as far as Israel is concerned), as a general matter and also in various stipulations concerning specific issues in the territories. ${ }^{102}$ The

98 CRC (n 33), Art 2(1). Also, CRC Protocol 3 (n 45) references in its preamble that '[n]oting that the States parties to the Convention on the Rights of the Child [...] recognize the rights set forth in it to each child within their jurisdiction'.

99 Art 6(1) of both Protocols (n 33). See also Art 6(3).

100 See the discussion in Wilde ( $\mathrm{n} 47$ ), and sources cited therein.

101 Ibid.

102 For example, in its Observations concerning Israel and the CRC in 2002, the Committee prefaced its treatment of the issue by stating that ' $[\mathrm{g}]$ iven the responsibility of the State party for the implementation of the Convention in the occupied Palestinian territories'. CRC Committee, 'Concluding Observations on Israel' (4 October 2002) CRC/C/15/Add.195, para 2. This position is then implicit in 
affirmation by the ICJ also comes from a treatment of the Israel-Palestine situation in the Wall Advisory Opinion, where the Court, having reviewed the question of the extraterritorial application of the ICCPR - which contains, as mentioned, the 'jurisdiction' trigger for applicability - and concluded that this treaty 'is applicable in respect of acts of a State done in the exercise of its jurisdiction outside its territory' then turns to the CRC, quotes the 'jurisdiction' provision from the treaty, and simply asserts: '[t]hat Convention is therefore applicable' (within the occupied Palestinian territories, to Israel). ${ }^{103}$ Then in its decision in the DRCv Uganda case the Court expanded the Wall dictum articulated in relation to the ICCPR, stating that 'international human rights instruments are applicable "in respect of acts done by a State in the exercise of its jurisdiction outside its own territory", particularly in occupied territories', citing the Wall decision paragraphs which cover the ICCPR, the CRC and, as will be addressed further below, the ICESCR. ${ }^{104}$ This reformulation brings out what was implicit in the Wall pronouncements, that the logic of its assertion made in relation to the ICCPR applied to the ICESCR and the CRC, thereby casting the assertion as a general doctrine and, moreover, one operative with respect to 'international human rights instruments' generally, not just these three particular treaties. It follows this with a list of human rights treaties, including the CRC and CRC Protocol 2, asserting that it considers them to be 'applicable, as relevant' (which in the context of the case meant applicable extraterritorially). ${ }^{105}$ This logic is clearly transferable to CRC Protocol 1 (which, regrettably, was not addressed in the case, despite prostitution being a common practice in wartime, and both states being parties to it at the relevant time). ${ }^{106}$ More broadly, these approaches are clearly transferable to the Arab Charter, which has not yet been subject to adjudication on the question of its extraterritorial applicability.

\section{c. Read into ICESCR and AfCHPR, and Defined Extraterritorially, Leading to a Hybrid Model of Applicability}

\section{i. Reading 'jurisdiction' into treaties that do not contain it as an express general provision}

The foregoing treatment of the subject of extraterritorial applicability by the ICJ in the Wall Advisory Opinion and the DRC v Uganda decision also takes in, as indicated, the ICESCR and, in the case of the DRC v Uganda decision, the AfCHPR, both of which, unlike the CRC and CRC Protocol 2, adopt a 'free standing' rather than a 'jurisdiction' approach to general applicability.

When it comes to the ICESCR in the Wall Advisory Opinion, the ICJ observes that since Article 14 ICESCR, concerning one particular right (education), references 'metropolitan territory or other territories under its jurisdiction', extraterritorial applicability of the treaty

various assertions about particular situations in the territories (paras 4, 5, 14, 15, 20, 26, 36-37, 44-45, $50,52-53,57-58,62)$.

${ }_{103}$ Legal Consequences of the Construction of a Wall in the Occupied Palestinian Territory, 2004 ICJ 136, paras 108-11 (on the ICCPR), 113 (on the CRC) (Advisory Opinion of 9 July).

104 Armed Activities on the Territory of the Congo (DRCv Uganda) 2005 ICJ 168, para 216 (Judgment of 19 December), citing the Wall Advisory Opinion (n 103), paras 107-13.

105 DRC v Uganda (n 104), para 217.

106 Information on the DRC and Uganda being parties to the Protocol taken from here: <https:// indicators.ohchr.org/> (29 November 2019). 
generally 'is not to be excluded'. ${ }^{107}$ The Court then invokes the treatment of the extraterritorial applicability of the treaty as far as Israel is concerned (the state at issue in the Wall Opinion) by the ICESCR Committee, which utilizes the 'jurisdiction' test for the extraterritorial applicability of the ICESCR, and defines this extraterritorially as the exercise of 'effective control'. ${ }^{108}$ The Court cites the Committee's use of 'effective control' in particular, and then rejects what it describes as Israel's refusenik position on applicability, stating that the Palestinian territories are subject to Israel's 'territorial jurisdiction' (which in this context means extraterritorial jurisdiction - the Court was not somehow treating the territories as part of Israel's sovereign territory, quite the reverse), and that 'in the exercise of the powers available to it on this basis' Israel is bound by the ICESCR. ${ }^{109}$ Then in DRC v Uganda, as mentioned earlier, the Court pronounces a general doctrine for the extraterritorial application of a set of human rights treaties - which includes the ICESCR and the AfCHPR - based on an expansion of the dictum from the Wall Advisory Opinion about the ICCPR, that 'international human rights instruments are applicable "in respect of acts done by a State in the exercise of its jurisdiction outside its own territory", particularly in occupied territories'. ${ }^{110}$

Unlike with the CRC and CRC Protocol 2, what is significant about these approaches to the ICESCR and the AfCHPR by the ICJ and (in the case of the latter instrument) the CESCR is that they appear to 'read in' the 'jurisdiction' regime for applicability, including extraterritorial applicability, both directly (this word is used when determining the question of extraterritorial applicability) and indirectly (the 'effective control' basis for extraterritorial applicability which, as mentioned, is the way the term 'jurisdiction' has been defined in this context - is utilized by the ICESCR Committee, and this is quoted by the ICJ), to treaties that do not use this word expressly as a general term to denote the scope of applicability (although the ICESCR does utilize it in Article 14 with respect to one right in particular).

\section{ii. The effect: hybrid 'free standing' and 'jurisdiction' regimes of applicability}

As indicated earlier, the CESCR has considered the extraterritorial application of the ICESCR extensively as a 'free standing' concept, without reference to the jurisdiction concept which it and the ICJ separately deployed when considering Israel in the Palestinian territories and, in the case of the ICJ, Uganda in the DRC - both being situations of occupation involving effective control exercised extraterritorially. Thus, it would seem, the approach to applicability based on the jurisdiction concept, arising when 'effective control' is exercised extraterritorially, is complementary to, not a substitute for, the 'free standing' approach. In consequence, there are two regimes of applicability: first, a 'free standing' approach generally (for example, in the

107 Wall (n 103), para 112.

108 See CESCR, 'Concluding Observations to the Initial Report' (4 December 1998) UN Doc E/C.12/1/Add.27, paras 6, 8 (the latter quoted by the ICJ in the Wall Advisory Opinion, para 112); 'Second Periodic Report', Add.32, paras 6-8 (para 5 quoted by the ICJ in the Wall Advisory Opinion, para 112); 'Concluding Observations to Second Periodic Report' (26 June 2003) UN Doc E/C.12/1/ Add.90, paras 15, 31 (cited in the Wall Advisory Opinion, para 112). See also the later decisions of CESCR 'Concluding Observations on Third Periodic Report of Israel' (16 December 2011) UN Doc E/C.12/ISR/CO/3, para 8; 'Concluding Observations on Fourth Periodic Report of Israel' (12 November 2019) UN Doc E/C.12/ISR/CO/4, paras 8 and 9.

109 Wall (n 103), para 112.

${ }^{110}$ DRC v Uganda (n 104), paras 216-17: the quote is from para 216, and it is quoting the Wall Advisory Opinion, para 111 (which is only about the ICCPR). 
ICESCR, to 'take steps'), which has an extraterritorial element to it, and, second, an approach focused on the specific exercise of effective control extraterritorially, whereby applicability operates on the basis of the concept of 'jurisdiction' being read into the treaty.

Bearing in mind what was said earlier about the potential transferability of the approach to the extraterritorial operation of the 'free standing' model of extraterritorial applicability in the ICESCR to the AfCHPR, and the reading in of the 'jurisdiction' trigger for extraterritorial applicability adopted by the ICJ in relation to the latter instrument, that instrument would seem similarly to operate in this hybrid manner.

More broadly, bearing in mind what was said earlier about the potential transferability of the approach to the extraterritorial operation of the 'free standing' model of extraterritorial applicability adopted in relation to the ICESCR to not only the AfCHPR but also the CRPD and the I-A PESC, and the equivalent approach adopted in relation to CERD to the AfCHPR Protocol on the Rights of Women, CEDAW and CIADDIS, it could also be said that all these treaties, like the ICESCR and the AfCHPR, can operate in a hybrid fashion, their extraterritorial applicability also being potentially operable on the basis of the 'jurisdiction' approach being read into them.

\section{d. The CRC and its Protocols 1 and 2}

A different 'hybrid' approach is evident in the CRC and its Protocols 1 and 2. In these treaties, as mentioned, the 'jurisdiction' regime for extraterritorial applicability, based on effective control, is operative for all the provisions therein, including those with economic implications, based on express references to this term rather than it being read into the treaties. However, additional stipulations are then made for economic, social and cultural rights in particular.

In the case of the $\mathrm{CRC}$, the provision states that:

States Parties shall undertake all appropriate legislative, administrative, and other measures for the implementation of the rights recognized in the present Convention. With regard to economic, social and cultural rights, States Parties shall undertake such measures to the maximum extent of their available resources and, where needed, within the framework of international co-operation. ${ }^{111}$

This provision uses some of the language contained in Article 2(1) ICESCR, but unlike that provision, with its obligation to 'take steps [...] to achieve progressively the full realization of the rights' in the treaty, this is not the source of the primary obligation to secure the rights in the treaty; that is contained in the separate 'jurisdiction' clause. The 'implementation of the rights' in the treaty being referred to here is therefore what is set out in that clause - the obligation to secure in the 'jurisdiction' - which then, in the case of economic, social and cultural rights, is to be done 'where needed, within the framework of international co-operation'. This is of a different character, then, from the free standing obligation to 'take steps' in the ICESCR. Whether or not it would have an extraterritorial dimension would depend on whether or not the general 'jurisdiction' regime has this, which in turn would arise, according to the standard approach, if there is the exercise of effective control extraterritorially. Absent that unusual situation, there would be no other extraterritorial obligation to secure such rights, unlike in the ICESCR. Thus the requirement of operating 'within the framework of international

111 CRC (n 33), Art 4. 
co-operation' would be only a matter of being the beneficiary of this for domestic realization of rights, not also, if the means existed, in being involved in the securing of such rights in other countries. The reference to engaging in international cooperation 'where needed', a term that is not used in the ICESCR, would therefore seem to mean 'need' in the sense of the situation in the state in question only, not also the situation in other states if the state was in a position to assist - in other words, to refer only to states in a socio-economically disadvantaged position, not also those in a socio-economically privileged position. If this is correct, then cooperation, in terms of material assistance, from those other states would not be a matter of this treaty (apart from in unusual situations when they exercise effective control in that state's territory), but would have to come from their general obligations in this regard, which would take things back to the other relevant instruments reviewed above.

Things are different, however, in Protocols 1 and 2 to the CRC, which concern the suppression of child prostitution and pornography and protecting children from involvement in armed conflict, respectively. As mentioned earlier, as well as having general regimes of applicability using the 'jurisdiction' concept, those treaties also contain specific stipulations that cover not only cooperation in general but also assistance specifically, with, crucially, the latter requiring the provision of assistance internationally by 'states in a position to do so' in particular. ${ }^{12}$ This echoes the language used by the CESCR, reviewed above, which is clearly a reference to socio-economically privileged countries, and is therefore concerned with such states having an extraterritorial obligation with respect to the realization, in other countries, of the rights contained in the treaties. The implications of this for economic assistance are especially significant in CRC Protocol 1, given that, as mentioned, its provisions on international cooperation include a focus on the 'root causes, such as poverty and underdevelopment' contributing to the vulnerability of children when it comes to involvement in prostitution and pornography, and in CRC Protocol 2, given that cooperation is to include the issue of the 'rehabilitation and social reintegration of persons who are victims' as a result of involvement in armed conflict. ${ }^{113}$

\section{e. Potential for Socio-Economic, Colonial and Environmental Justice Across Borders}

Bringing together what has been covered in the present section on the 'jurisdiction' regime for applicability: the treaties that use this term expressly - the Arab Charter, the CRC and CRC Protocols 1 and 2, and the treaties that it has been 'read into', the AfCHPR and the ICCPR, and by association, the other treaties it could be 'read into', the AfCHPR Protocol on the Rights of Women, CEDAW, CERD, CIADDIS, CRPD and the I-A PESC - can be interpreted to apply extraterritorially in the specific context where effective control is exercised over territory, such as in an occupation situation. In such circumstances, a state would have a general obligation to realize socio-economic rights.

The general significance, to the present question of global economic, colonial and environmental justice, of the effective territorial control basis for applying obligations is limited, since this basis is concerned with responsibility only when a narrowly defined kinetic power relationship exists. The alternative generalized approach, therefore, is of much broader significance.

112 See above, text accompanying notes 64 and 65 .

113 CRC Protocol 1 (n 33), Art 10 (quotation from para 3); CRC Protocol 2 (n 33), Art 7. 
That said, within the narrow class of situations involving effective territorial control, having obligations then triggered in a generalized sense is potentially important. Power relations of this kind are usually practised by economically privileged states over territories that are relatively less economically privileged - whether in the case of military occupations, or remaining formal colonial arrangements (to adopt the way international law frames these arrangements and categories, which has its problems, obviously). Indeed, the sharp difference in economic standing is usually a key factor in how it is possible to establish the control relationship in the first place, why this is done by the controlling state and also what effect the relationship has, when it involves, as is usually the case, economic exploitation. Where, then, such relationships exist, a regime of obligations concerning the protection of social rights is highly relevant. Indeed, such obligations would have the potential to challenge the economically exploitative nature of such arrangements. As such, this regime would speak to aspects of the colonial justice agenda even if it would not, by itself, address the fundamental question of ending the arrangement (something which would be a matter for the law of self-determination, which does form part of human rights law).

The provisions made in the two CRC Protocols open the focus out from situations of direct territorial control to a generalized approach evident in the alternative 'free standing' regime of extraterritorial applicability. Under the Protocols, states 'in a position to do so', that is, those which are economically privileged, are under an obligation to provide 'assistance' in the context of international cooperation, concerning the implementation of the Protocols, with specific stipulations in relation to child pornography and prostitution that this address 'root causes, such as poverty and underdevelopment' contributing to the vulnerability of children, and the 'rehabilitation and social reintegration of persons who are victims' through being involved, as children, in armed conflict.

\section{CONCLUSIONS}

In his manifesto for 'post-colonial' approaches to the global system of law and governance that would address many aspects of the three challenges referred to at the start of this piece, Chimni observes:

Few would deny that the globalization of human rights does offer an important basis for advancing the cause of the poor and the marginal in third world countries. Even the focus on civil and political rights is helpful in the struggle against the harmful policies of the State and international institutions [...]. But it is equally true that the focus allows the pursuit of the neo-liberal agenda by privileging private rights over social and economic rights. ${ }^{114}$

Chimni ultimately chooses not to discard entirely the 'human rights' agenda, as some others have done (as mentioned above). For him, when it comes to international law in general, 'we need to guard against the trap of legal nihilism through indulging in a general and complete condemnation of contemporary international law'. ${ }^{115}$ He observes that

114 Chimni (n 6), 18.

115 Ibid., 26. 
[t] he contradictions which mark contemporary international law [are ...] manifested in the field of international human rights law which even as it legitimizes the internationalization of property rights and hegemonic interventions, codifies a range of civil, political, social, cultural and economic rights which can be invoked on behalf of the poor and the marginal groups. It holds out the hope that the international legal process can be used to bring a modicum of welfare to long suffering peoples of the third and first worlds. ${ }^{116}$

He therefore argues that 'there is the need to make effective use of the language of human rights to defend the interests of the poor and marginal groups'. ${ }^{117}$

The present chapter has attempted to offer one contribution to such an effort, by making the case for the possibility that the provisions of all the human rights treaties that contain socio-economic rights can be interpreted to have an extraterritorial dimension. This creates the potential for the treaties to be able to address issue of economic, colonial and environmental justice across borders in general and as concerns the realization of social rights in particular. This interpretative potential has been realized, in the sense that it has been positively affirmed by authoritative interpretative bodies (such as the ICJ and the CESCR), across a representative subset of the relevant treaties, and the logic of these affirmations is transferable to the other treaties.

Extraterritorial applicability is possible in two distinct circumstances, with different potential when it comes to the significance for economic, colonial and environmental justice across borders. First is the 'free standing' model of applicability that operates with respect to the AfCHPR and its Protocol on the Rights of Women, CEDAW, CERD, CIADDIS, CRPD, the I-A PESC and the ICESCR, as well as certain specific obligations in CRC Protocols 1 and 2. This has the potential to encompass a duty on the part of states in a position to do so to engage in economic transfers across borders to realize social rights. States with the greatest economic privileges would bear the greater substantive duties in terms of the levels of resources provided.

Second is the 'jurisdiction' basis of applicability that is contained in express provisions in the Arab Charter, CRC, CRC Protocols 1 and 2, has been read in to the ICESCR and AfCHPR, and can be, following this logic, also read into the AfCHPR Protocol on the Rights of Women, CEDAW, CERD, CIADDIS, CRPD and the I-A PESC. It applies extraterritorially when states exercise direct kinetic control over territory, such as in occupation situations. States are then required to secure social rights in a generalized sense, something which has clear potential implications for economic transfers to enable this when they are in an economically privileged position to do so, and where the condition of social rights in the territory in question requires it. Such a position, and such requirements, are of course typically evident in situations where states exercise effective control over foreign territory, such as in military occupations and colonial arrangements.

Establishing how the treaty provisions can be interpreted in the two foregoing approaches is only the starting point in terms of the potential for these provisions to be the basis for an obligation to engage in economic transfers across borders to secure social rights. The next step, which is beyond the scope of the present chapter, is to establish the crucial question of what quantum of social provision is and should be required. This depends on two hugely

116 Ibid., 26-27.

117 Ibid., 24. 
contested matters. ${ }^{118}$ In the first place is the general question for social rights of how the 'progressive' test, whereby states are required to secure such rights through social provision at levels that are contingent on available resources, can and should be interpreted given that what is 'available' is not a fixed matter but is of course determined by the particular economic/ fiscal model adopted by any given state. In the second place is then a specific question raised by the extraterritorial orientation at issue: how is and should a balance be struck between securing social rights within a state's own territory, and doing so extraterritorially? And what difference in this regard should operate as far as the generalized 'free standing' extraterritorial obligations, as distinct from obligations triggered when states exercise direct kinetic control extraterritorially? In addressing these and other questions, it will also be necessary to situate the treaty regimes within the broader normative framework and to revisit the aforementioned 'soft law' regimes, notably concerning the right to development, and the commitments OECD states have made to certain levels of so-called development assistance and, more generally, international environmental law. States' obligations in international law have to be considered in the round, not on the basis of a partial view taking in only a subset of the relevant normative frameworks. ${ }^{119}$ It may be, for example, that the interplay between the 'hard' and 'soft' regimes has normative significance, and that the latter, while insufficient to be formally binding by itself, can be read into the former, in turn providing greater specificity and substantive content than is evident in and possible from an exclusive focus on the treaty regimes.

118 See further the discussion in Wilde (n 20), 151-55, 162-63, 164-67 and sources cited therein.

119 For a holistic approach, see the writing of Dinah Shelton, for example Shelton ( $\mathrm{n} 9$ ), section E. The HRCttee made the following observation in the context of the right to life under Article 6 of the ICCPR, and the environment: 'Environmental degradation, climate change and unsustainable development constitute some of the most pressing and serious threats to the ability of present and future generations to enjoy the right to life. Obligations of States parties under international environmental law should thus inform the contents of article 6 of the Covenant, and the obligation of States parties to respect and ensure the right to life should also inform their relevant obligations under international environmental law' (HRCttee (GC 36) (n 32), para 62). 